cover ethics, pharmacology, psychoanalysis, attentiondeficit hyperactivity disorder, global and cultural psychiatry, and mental health policy initiatives, as well as articles and commentaries on many other subjects.

O M onthly W PA electronic bulletin. All psychiatrists can obtain extensive up-to-date information about international news, publications and conferences (and much more) by signing on electronically to the monthly eBulletin of the WPA. See www.w panet.org/sectorial/ bulletin/suscript.php.

\section{The North American Group of the Royal College of Psychiatrists}

For more than 20 years this Group has received members and visitors at the annual meetings of the American Psychiatric Association (APA) and this tradition will continue in 2004 in N ew York City, probably on 2 May (see Forthcoming international events). The 2003 meeting in San Francisco was fun, with good food, drink, company and brief, lively speeches by Mike Shooter, Robin Murray and Paul Jessop. 0 ur activities now include scientific presentations at both the APA and College meetings. 0 ur to pics in the USA have ranged from risk factors in schizophrenia and the history of schizophrenia, to war, terrorism and refugees, with experts from several countries and cultures, sometimes speaking to overflowing audiences. Topics at the College meetings have included ' $\mathrm{H}$ ot topics in American psychiatry', 'Suicide in the elderly and physician-assisted suicide', 'Lessons learned in disaster psychiatry for children after 9/11 in N ew York' and 'W hat happened to the severely mentally ill after deinstitutionalisation'.

For the 2004 APA meeting symposium we have submitted proposals on 'The provision of psychiatric services where there is a shortage of psychiatrists', with speakers from five countries, and a workshop entitled 'Psychiatry in Afghanistan and Afghan refugees'.

For the College's 2004 annual meeting in H arrogate there will be a session on 'Serving the underserved in the US' (the elderly, children and those with severe mental illnesses).

All these events have been organised and chaired by the chair of the Group, N igel Bark.

\title{
Forthcoming international events
}

\section{January 2004}

Conference on Religious Psychopathology

Foundation for Psychiatry and Religion in collaboration with the WPA Section on Religion, Spirituality and Psychiatry.

Amsterdam, The $\mathrm{N}$ etherlands.

Contact: Dr Herman M. Van Praag.

Email: h.m.van.praag@vanpraag.com.

\section{January- 2 February 2004}

International Conference on Schizophrenia

WPA co-sponsored conference. Schizophrenia Research Foundation (SCARF) in collaboration with the WHO.

Chennai (O ld Madras), India.

Contact: Dr R. Thara.

Email: scarf@vsnl.com.

Website: www.scarfindia.org.

\section{1-28 February 2004}

Fifth Virtual Congress of Psychiatry

(interpsiquis 2004)

Palma de Mallorca, Spain.

Contact: Dr Pedro Moreno.

Email: secretaria@ psiquiatria.com.

Website: www.interpsiquis.com/2004/particiption.html.

\section{2- 14 February 2004}

Bienestar y Calidad de Vida en el Siglo XXI

WPA Section on Mass Media and Mental Health, with Havana Psychiatric Hospital.

Havana, Cuba.

Contact: Dr Miguel A. Materazzi.

Email: materazzi@ arnet.com.ar.

\section{5- 10 March 2004}

Second Biennial Conference of the International Society for Affective D isorders (ISAD)

WPA co-sponsored conference. In collaboration with the WPA Section on Affective Disorders.

Cancun, Mexico.

Contact: D avid Beck.

Email: d.k.beck@ soton.ac.uk.

Website: www.isad.org.uk.

\author{
17-20 March 2004 \\ Second World Congress on Women's Mental Health \\ WPA Section on Women's Mental Health and the W PA Section \\ on Interdisciplinary Collaboration. \\ Washington, DC, USA. \\ Contact: Dr Donna Stewart; Dr U riel Halbreich. \\ Email:donna.stewart@uhn.on.ca; urielh@ acsu.buffalo.edu. \\ Website: www.womenmentalhealth.com.
}

\section{7-20 March 2004}

$\mathrm{N}$ ational Association of Dually Diagnosed. International Congress - V

In collaboration with the WPA Section on Mental Retardation.

Boston, Massachusetts, USA.

Contact: Dr L. Salvador Carulla.

Email: I.Salvador@ telefonica.net.

\section{3-25 March 2004}

First International Conference on Psychiatry, Law and Ethics WPA Section on Psychiatry, Law and Ethics in collaboration with UNESCO, WAML, ICLE and SMLI.

Eilat, Israel.

Email: seminars@ isas.co.il.

Website: www.isas.co.il/psychiatrylaw 2004.

\section{March-2 April 2004}

Congreso Panamericano de Salud Mental Infanto-Juvenil $O$ rganised by Cuban Society of Psychiatry in collaboration with the WHO and the Latin American Psychiatric Association.

Palacio de Convenciones, Havana, Cuba.

Contact: Dr Cristobal Martinez Gomez.

Email: crisma@ informed.sld.cu.

Website: www.sld.cu/eventos/psiquiatria/felices;

www.loseventos.cu/saludmental2004.

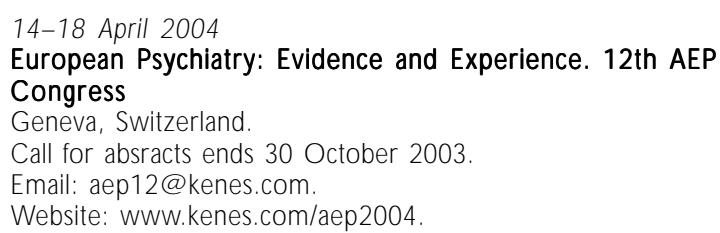


1- 6 May 2004

American Psychiatric Association Annual Congress

N ew York, USA.

Contact: apa@psych.org.

Website: www.psych.org.

14- 19 May 2004

History of Psychiatry: 18th Congress of the Hellenic

Psychiatric Association

In collaboration with W PA Sections on History of Psychiatry and Humanities in Psychiatry.

Island of Kos, Greece.

Contact: Prof. George Christodoulou, Hellenic Psychiatric Associ-

ation, 11, Papadiamandopoulou str., 11528 Athens, Greece.

Fax: + 302107242032

Email: gnchrist@ compulink.gr.

27-29 May 2004

International Conference on Education and Promotion in

Mental Health

The annual conference of Mental Health Europe.

Liubjana, Slovenia.

Contact: Mental Health Europe, Boulevard Clovis7, B-1000

Brussels, Belgium.

Tel: + 3222800468 .

Email: info@mhe-sme.org.

10 June 2004

Poder de la Resiliencia en el Desajuste Social Actual

WPA Section on Mass Media and Mental Health in

collaboration with Hospital Psiquiatrico Jose T. Borda.

Buenos Aires, Argentina.

Contact: Dr. Miguel A. Materazzi.

Email: materazzi@ arnet.com.ar.

25-27 June 2004

XVIII Peruvian Psychiatric Congress and III Regional

Meeting of the APAL

WPA co-sponsored conference.

Lima, Peru.

Contact: Dr Elard Sanchez Tejada.

Email: app@ amauta.rcp.net.pe.

\section{6-9 July 2004}

Royal College of Psychiatrists Annual Meeting

International Centre, $\mathrm{H}$ arrogate, UK.

Contact: College Conference 0 ffice.

Tel: $+44(0) 2072352351 \times 142$.

Fax: + 44 (0)20 72596507

Email: mbraithwaite@ rcpsych.ac.uk.

4-8 August 2004

Solidarity/M oral D isplacement

Stockholm Group Conference on Social Issues and International

Association of Group Psychotherapy.

Email: Soci2004@ hotmail.com

Website: www.psykoterapisallskapet.se.

17-19 September 2004

WPA Regional Meeting

Mental Health Resource Center (MHRC) in collaboration with the Pakistan Psychiatric Society.

Lahore, Pakistan.

Contact: Dr Haroon Rashid Chaudry.

Email: pprc@wol.net.pk.

22-26 September 2004

14th World Congress of the World Association for

Dynamic Psychiatry (W ADP)

WPA co-sponsored conference.

Cracow, Poland

Contact: Dr Maria Ammon.

Email: wadp.congress2004@ dynpsych.de.

28 September- 1 October 2004

Translating the Evidence. International Early Psychosis

Association

Vancouver, Canada.

Contact: congress@venuewest.com

Website: www.iepa.org.au.
6- 9 October 2004

8th Congress of the International Association for the

Treatment of Sexual 0 ffenders (IATSO)

W PA co-sponsored conference.

Athens, Greece.

Contact: Dr O restis Giotakos.

Email: giotakos@ tri.forthnet.gr.

Website: www.iatsoathens.gr.

7-10 October 2004

Mental Health Perspectives in Public Health Conference

WPA co-sponsored conference. Armenian Association of Psychiatrists and $\mathrm{N}$ arcologists.

Yerevan, Armenia.

Contact: Dr Armen Soghoyan.

Email: majoria@arminco.com

8-10 October 2004

The Individual and the Group: Bridging the $\mathbf{G}$ ap

EFPP Conference on Psychoanalytic Group Psychotherapy.

Lisbon, Portugal.

Email: admedic@mail.telepac.pt.

Website: www.efpp.org.

24-26 October 2004

3rd World Congress on Men's Health

W PA co-sponsored conference. International Society for Men's

Health in collaboration with the International Forum of Mood and Anxiety Disorder and the Austrian Association of

N europharmacology.

Vienna, Austria.

Contact: Dr Siegfried Kasper.

Email: sk@akh-wien.ac.at.

Website: www.wchm.info.

24-27 October 2004

XVIII World Congress of W orld Association for Social Psychiatry

The Japanese Society of Social Psychiatry in collaboration with the $\mathrm{WHO}$.

Kobe, Japan.

Contact: Dr Yoshibumi Nakane.

Email: yonakane@ net.nagasaki-u.ac.jp.

Website: www.congre.co.jp/18wasp.

10-13 November 2004

Treatment in Psychiatry: An Update

International Congress of the WPA.

Florence, Italy.

Contact: Prof. Mario Maj, Institute of Psychiatry, U niversity of N aples, Largo Madonna Delle Grazie, I-80138, Italy. Fax: + 390815666523

Email: majmario@ tin.it.

\section{2- 15 January 2005}

Facing the Challenges, Building Solutions

WHO Ministerial Conference on Mental Health. An invitational conference of all 52 member states in the WHO European

Region and of selected organisations.

Contact: Mental Health Programme, Regional O ffice for Europe, Scherfigsvej 8, DK 2100, Copenhagen, Denmark. Fax: + 4539171865 .

Email: jke@ euro.who.int.

12-15 March 2005

Advances in Psychiatry and Meeting of the WPA Scientific Sections

WPA Regional Meeting

Athens, Greece.

Contact: Prof. George Christodoulou, Athens University

Department of Psychiatry, Eginition Hospital, 74, Vasilissis

Sophias, 11528 Athens, Greece.

Fax: + 302107242032

Email:gnchrist@ compulink.gr.

21-26 May 2005

American Psychiatric Association Annual Congress

Atlanta, GA, USA.

Contact: apa@psych.org

Website: www.psych.org 